\title{
The Effect of Resilience on the Quality of Life and Psychological Symptoms on Incarcerated Women
}

\author{
Talitha Lintang Pertiwi ${ }^{1, *}$, Dian Veronika Sakti Kaloeti ${ }^{2}$ \\ ${ }^{1}$ Master Program of Psychology, Fakultas Psikologi, Universitas Diponegoro, Semarang, Indonesia \\ ${ }^{2}$ Family Empowerment Center, Fakultas Psikologi, Universitas Diponegoro, Semarang, Indonesia \\ *Corresponding author. Email: talithalintang@students.undip.ac.id
}

\begin{abstract}
It is known that incarcerated women have problems that affect their psychological condition, such as experiencing depression and anxiety. Based on previous studies, the resilience and quality of life can minimize the depression and anxiety experience of the inmates in correctional institutions. This study aimed to determine the effect of resilience on incarcerated women's quality of life and psychological symptoms. In this study, 130 women prisoners with the age range of 25 to 54 participated. The sampling technique used was purposive sampling with three instruments, the Connor-Davidson Resilience Scale 10 (CD-RISC 10) $(\alpha=0.896)$, the World Health Organization Quality of Life (WHOQOL-BREF) ( $\alpha=0.930)$, and the Hopkins Symptom Checklist -25 (HSCL-25) $(\alpha=0.928)$. Partial Least Square Structural Equation Modeling (PLS-SEM) was utilized for the analysis. Resilience significantly affected all aspects of the quality of life. The more resilient a person was, the higher the quality of her life would be. Quality of life, in regards to social relationships, would reduce the anxiety and depression level. The mother's psychological situation would influence depression and be moderately affected by their children's awareness of his mother's imprisonment. The mother's quality of life, in terms of physical health, would affect anxiety, which was influenced by the marriage status, where divorce affected the quality of life, impacting anxiety. The future implications were discussed.
\end{abstract}

Keywords: Resilience, Quality of Life, Psychological Symptoms, Incarcerated Women.

\section{INTRODUCTION}

The convicts in the correctional facility face many problems that affect their psychological condition and mental health. Some issues that exist include the loss of family, the loss of control, the loss of models, and the loss of support. The inmates will also experience a new different life than outside the prison. For example, losing the opportunity to contact the opposite sex, losing the right to freely determine their wishes, losing property rights, and losing their sense of security. This experience is highly potential to cause both physical and psychological disorders [1].

Incarcerated women have a much higher need in place of men when in prison. Negy et al. [2] reported that male and female offenders have the same experience in prison. However, women inmates experience more psychological problems from the pressure of sustaining an intact child care role. Nevertheless, being in a correctional facility may limit their role.
Herdiana's research [3] was conducted in a woman in prison. It states several findings among all affected subjects regarding the personality factors and situations while acting as wife and mother. A preliminary study conducted by Pamungkas [4] reported the data from 15 people in which 11 of the incarcerated women experienced mild stress. Three of them experienced moderate pressure, and one convict experienced severe stress.

A study has reported that regular treatment at regular intervals can improve individuals' quality of life [5]. One of the psychological treatments that are being developed is the treatment to increase resistance. According to Walsh [6], resilience is an individuals' ability to adapt and cope with everyday stress, changing lives, and progressive development. Studies show that resilience influences the quality of life [7]. Azzahra [1] stated that individual resilience skills could affect personal psychological distress. Several studies regarding resilience and its influence on the quality of life have been carried out in the general public and certain ages, for example, adolescents [8] 
and adults [9]. However, research on resilience and its impact on inmates' quality of life, especially female offenders, is still rare.

Therefore, the study aimed to investigate the effect of resilience on the quality of life and psychological symptoms of incarcerated women. The quality of life would predict anxiety and depression influenced by their children's awareness and marital status.

\section{METHOD}

\subsection{Research Participants}

The participants of this study were 130 incarcerated women. The sampling technique used was purposive sampling, with participant inclusion criteria: 1 . female, 2 . already receive a verdict, 3 . have at least 1 child, 4 . willing to fill out a questionnaire with informed consent.

\subsection{Research Instruments}

This study used three instruments, namely the Connor-Davidson Resilience Scale 10 (CD-RISC 10), the World Health Organization Quality of Life (WHOQOL-BREF), and the Hopkins Symptom Checklist-25 (HSCL-25).

Connor-Davidson Resilience Scale 10 (CD-RISC 10) was used to measure the level of individual resilience [10]. Connor-Davidson Resilience Scale 10 (CD-RISC 10) consisted of 10 items. With example item: "I can adapt to changes that occur." and graded using Likert scale of 1 (never) - 5 (almost always). The sum of the scores obtained from questions 1-10 showed the level of individual resilience. The higher the score obtained, the higher the level of resilience. The categorization of scores has been translated by Campbell et al. [11] into four categories of low (0-29), moderate (30-32), high (33-36), and very high (37-40). The reliability coefficient of the Connor-Davidson Resilience Scale 10 (CD-RISC 10) in this study was 0.896 .

WHOQOL-BREF was used to measure individuals' quality of life [12]. The 26 items in WHOQOL-BREF consisted of 4 domains, QoL1 = Physical Health (example item: How much does your physical pain prevent you from doing activities according to your needs?), QoL2 = Psychological (example item: How much do you enjoy your life?), QoL3 = Social Relationships (example item: How satisfied are you with your sexual life?), and QoL4 = The Environment (example item: How healthy is the environment at the place you live? (related to facilities and infrastructure)). The WHOQOL-BREF assessment carried a Likert scale of 1 (rarely) to 5 (very often). The reliability coefficient in this study was 0.93. The total number of WHOQOL-BREF entries described the condition of the individual's quality of life.

The Hopkins Symptom Checklist-25 (HSCL-25) was used to measure psychological symptoms, such as anxiety and depression [13]. The Hopkins Symptom Checklist-25 (HSCL-25) consisted of 25 items. The Hopkins Symptom Checklist-25 (HSCL-25) scale used a Likert scale from 1 (absolutely never) to 4 (often). There were two parts of the Hopkins Symptom Checklist-25 (HSCL-25), depression and anxiety. Part depression consisted of 15 items (example item: Thinking about ending your life). While the part anxiety was of 10 items (example item: Suddenly feeling scared for no apparent reason). The mean of the sum of the scores described the condition sensed by the individual. Cut off points $\geq 1.75$ indicated that the individual has depression and anxiety [14]. The higher the score obtained, the higher the level of depression and anxiety. The Hopkins Symptom Checklist-25 (HSCL-25) reliability coefficient in this study was 0.928 .

\section{RESULTS AND DISCUSSION}

\subsection{Results}

\subsubsection{Demographic Description of Research Participants}

Participants in this study were 130 incarcerated women aged 25-54 years old. The participants mostly are of Javanese descent $(80.84 \%)$, graduated from high school $(63.8 \%)$, admitted to prison for the first time (\%), with the most cases being drugs $(71.5 \%)$. In addition, more than half of the respondents were married $(59.97 \%)$. A detailed description of this research demographic can be seen in Table 1. 
Table 1. Demographic description of research participants

\begin{tabular}{|c|c|c|}
\hline \multirow[b]{2}{*}{ Category } & \multicolumn{2}{|c|}{ Total } \\
\hline & $\begin{array}{c}\text { Number of } \\
\text { People }\end{array}$ & $\%$ \\
\hline \multicolumn{3}{|l|}{ Gender } \\
\hline Female & 130 & 100 \\
\hline \multicolumn{3}{|l|}{ Age } \\
\hline $15-34$ & 1 & 0.76 \\
\hline $18-24$ & 9 & 6.92 \\
\hline $25-34$ & 39 & 30 \\
\hline $34-35$ & 1 & 0.76 \\
\hline $35-44$ & 48 & 36.9 \\
\hline $45-54$ & 25 & 19.2 \\
\hline$>54$ & 7 & 5.38 \\
\hline \multicolumn{3}{|l|}{ Marital Status } \\
\hline Married & 78 & 59.97 \\
\hline Divorce & 40 & 30.7 \\
\hline Death Divorce & 12 & 9.2 \\
\hline \multicolumn{3}{|l|}{ Age of marriage } \\
\hline$<5$ & 34 & 26.1 \\
\hline $6-10$ & 52 & 40 \\
\hline $11-20$ & 27 & 16.1 \\
\hline$>20$ & 17 & 13.0 \\
\hline \multicolumn{3}{|c|}{ Family condition since imprisonment } \\
\hline It got really bad & 46 & 35.38 \\
\hline Being a little bad & 33 & 25.38 \\
\hline $\begin{array}{l}\text { It is the same / does not } \\
\text { change }\end{array}$ & 42 & 32.3 \\
\hline Be a little good & 5 & 3.84 \\
\hline
\end{tabular}

\subsubsection{Hypothesis testing}

A statistical power analysis was performed for sample size estimation. With a power value $>0.8$, shown in table 2, the sample size was adequate for this study's primary objective. It could confidently read the estimated results in the model.

Table 2. G-Power results (Primary data, 2020)

\begin{tabular}{|l|c|c|c|}
\hline Variable & $\begin{array}{c}\text { Number of } \\
\text { independent } \\
\text { variable(s) }\end{array}$ & $\begin{array}{c}\text { Size of } \\
\text { sample }\end{array}$ & $\begin{array}{c}\text { Statistical } \\
\text { Power } \\
\text { (Cut off } \\
\text { value >0.8) }\end{array}$ \\
\hline $\begin{array}{l}\text { Physical } \\
\text { Domain }\end{array}$ & 1 & 130 & 1 \\
\hline $\begin{array}{l}\text { Psychologic } \\
\text { al Domain }\end{array}$ & 1 & 130 & 1 \\
\hline $\begin{array}{l}\text { Social } \\
\text { relationship } \\
\text { Domain }\end{array}$ & 1 & 130 & 0.98 \\
\hline $\begin{array}{l}\text { Environmen } \\
\text { tal Domain }\end{array}$ & 1 & 130 & 0.99 \\
\hline
\end{tabular}

\begin{tabular}{|l|l|l|l|}
\hline Anxiety & 5 & 130 & 0.99 \\
\hline Depression & 5 & 130 & 0.95 \\
\hline
\end{tabular}

Structure Model testing through the coefficients of determination value $\left(\mathrm{R}^{2}\right)$ and Path Coefficients results as presented in table 3 to table 5.

Table 3. R Square value (Primary data, 2020)

\begin{tabular}{|c|c|c|}
\hline Variable & $\mathbf{R}^{\mathbf{2}}$ & \\
\hline Physical health & 0.329 & Moderate \\
\hline $\begin{array}{c}\text { Psychological } \\
\text { health }\end{array}$ & 0.368 & Moderate \\
\hline Social relationships & 0.114 & Weak \\
\hline Environmental & 0.259 & Moderate \\
\hline Anxiety & 0.268 & Moderate \\
\hline Depression & 0.139 & Weak \\
\hline
\end{tabular}

The coefficients of determination value $\left(\mathrm{R}^{2}\right)$ could be categorized as strong if the $R^{2}$ value $\geq 0.67$, moderate $\geq 0.33$, and weak $\geq 0.19$ [11]. Based on Table 3, four variables have moderate predictive accuracy ability of resilience. They were physical domain (32.9\%), psychological domain (36.8\%), environmental domain (25.9), and anxiety (26.8\%). Furthermore, the social relationship domain has a weak predictive accuracy ability for the resilience of $11.4 \%$ and depression of $13.9 \%$.

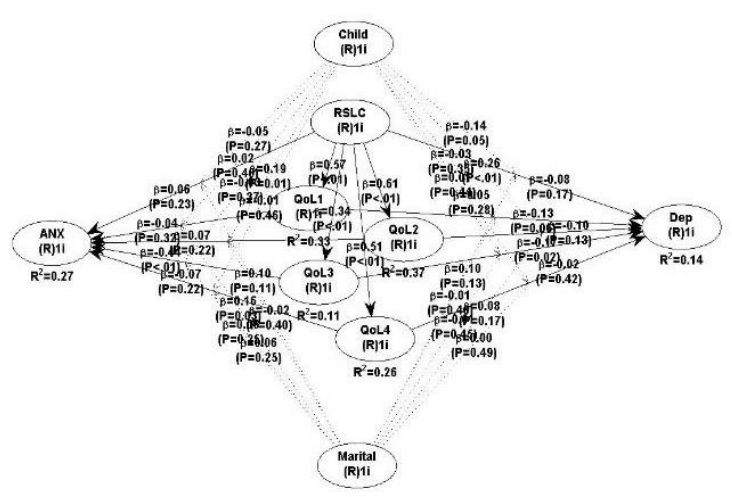

Figure 1. Modeling hypothesis result

Structural model testing aimed to determine whether there was an influence between variables in the model. The T-statistic value compared with the Ttable, which was $>1.96$ at a significance level of $5 \%$. The results in the original sample indicated the direction of a positive or negative relationship. At the same time, the $\mathrm{T}$ statistic showed the significance of 
the relationship. In Table 4, only significant results were provided.

Table 4. Direct effect results (Primary data, 2020)

\begin{tabular}{|c|c|c|c|c|}
\hline & $\beta$ & SE & $\begin{array}{c}\text { T - } \\
\text { statisti } \\
\text { c }\end{array}$ & $\begin{array}{c}p \text { - } \\
\text { value }\end{array}$ \\
\hline $\begin{array}{l}\text { Resilience } \rightarrow \\
\text { Physical } \\
\text { health }\end{array}$ & 0.574 & 0.076 & 7.553 & 0.001 \\
\hline $\begin{array}{l}\text { Resilience } \rightarrow \\
\text { Psychological } \\
\text { health }\end{array}$ & 0.607 & 0.076 & 7.987 & 0.001 \\
\hline $\begin{array}{l}\text { Resilience } \rightarrow \\
\text { Social } \\
\text { relationships }\end{array}$ & 0.338 & 0.081 & 4.173 & 0.001 \\
\hline $\begin{array}{l}\text { Resilience } \rightarrow \\
\text { Environmenta } \\
1\end{array}$ & 0.509 & 0.078 & 6.526 & 0.001 \\
\hline $\begin{array}{l}\text { Social } \\
\text { relationships } \\
\rightarrow \text { Anxiety }\end{array}$ & -0.437 & 0.079 & -5.532 & 0.001 \\
\hline $\begin{array}{l}\text { Social } \\
\text { relationships } \\
\rightarrow \text { Depression }\end{array}$ & -0.174 & 0.084 & -2.071 & 0.02 \\
\hline $\begin{array}{l}\text { Child*Psy } \\
\text { chological } \\
\text { health } \rightarrow \\
\text { Anxiety }\end{array}$ & 0.189 & 0.084 & 2.250 & 0.013 \\
\hline $\begin{array}{l}\text { Child*Psycho } \\
\text { logical } \\
\text { health } \rightarrow \\
\text { Depression }\end{array}$ & 0.259 & 0.082 & 3.159 & 0.001 \\
\hline $\begin{array}{l}\text { Marital*Physi } \\
\text { cal } \rightarrow \\
\text { Anxiety }\end{array}$ & 0.159 & 0.084 & 1.893 & 0.031 \\
\hline
\end{tabular}

Table 5. Indirect effect results (Primary data, 2020)

\begin{tabular}{|l|c|c|c|c|}
\hline & $\boldsymbol{\beta}$ & SE & $\begin{array}{c}\text { T - } \\
\text { statisti } \\
\text { c }\end{array}$ & $\begin{array}{c}\boldsymbol{p} \text { - } \\
\text { value }\end{array}$ \\
\hline $\begin{array}{l}\text { Resilience } \rightarrow \\
\text { Anxiety }\end{array}$ & -0.166 & 0.084 & -1.976 & 0.026 \\
\hline $\begin{array}{l}\text { Resilience } \rightarrow \\
\text { Depression }\end{array}$ & -0.204 & 0.084 & -2.429 & 0.008 \\
\hline
\end{tabular}

Based on Table 4, resilience had a significant positive effect on all Quality of Life aspects: Physical health (T-statistic $=7.553)$, Psychological health $(\mathrm{T}$ statistic $=7.987)$, Social relationships (T-statistic= 4.173), Environment $(\mathrm{T}$-statistic $=6.526)$. Social relationships had a negative significant effect on Anxiety (T-statistic $=-5.532)$, and Depression $(\mathrm{T}$ statistic $=-2.071)$. Children's awareness of their mothers' incarceration significantly moderated the relationship between psychological health and anxiety $(\mathrm{T}$-statistic $=2.250)$ and depression $(\mathrm{T}$-statistic $=$ 0.391). Marital status moderately influenced the relationship between physical health and anxiety ( $\mathrm{T}$ statistic=1.893); being divorced was related to higher anxiety. According to Table 5, Quality of Life had an indirect effect on the relationship of resilience and anxiety $(\beta=-0.166)$ along with depression $(\beta=$ $0.204)$.

\subsection{Discussion}

This study found that resilience had a significantly positive effect on all aspects of the quality of life, according to WHO, of physical health, psychological health, social relationships, and environment. The direction of the positive relationship between resilience and quality of life represented that the higher the individual resilience, the better the quality of life, and vice versa. This research was in line with the research by Batool et al. [7], which stated that resilience influenced the quality of life of individuals, as shown through good self-management and healthy body conditions.

We found that social relationships had a significant negative effect on anxiety and depression. The more resilient a person was, the individual was more able to manage her anxiety and regulate negative emotions. Mujahidah and Listiandini [15] state that resilience and empathy could influence depression in individuals. This was because resilience was considered as a protective factor for individuals from the threat of depression. Thus, resilient individuals would do things carefully, focused on solving problems, and could also adapt and control themselves to reduce anxiety and depression levels.

Social relationships had a dominantly negative effect on anxiety and depression. The higher the quality of social relationships, the lower the level of loss and depression. Social relationships have important implications for both physical and mental health. The state of one's social relationships can affect that person's overall health. According to the evidence from a recent review, good social relationships could prolong survival by $50 \%$ [16]. A seven-decade followup study discovered that social relationships were better predictors of health than a range of biological and economic factors [13]. Similarly, they reported that having poor [16] social relationships was potentially more harmful than excessive drinking and smoking, obesity, and lack of exercise. 
Meanwhile, children's awareness of their mother's situation moderately affected the relationship of psychological health, anxiety, and depression. If the child knew that their mother was a convict, it would affect the quality of life and increase the depression level of the imprisoned mothers. As in previous research [17], most incarcerated mothers in the present study experienced elevating depressive symptoms, multiple experiences of early loss, trauma, and relationship disconnection, as well as limited contact with their children during imprisonment.

\subsection{Conclusion}

This study discussed the effect of resilience on the quality of life and psychological symptoms of incarcerated women. The results revealed that the prisoners' resilience significantly affected the quality of life and psychological symptoms (depression and anxiety). Thus, resilient skills were considered capable of improving the quality of life and reducing psychological problems (depression and anxiety) experienced by the convicts. This study's results may provide recommendations to counselors and prison policyholders who are attempting to improve the quality of life and reduce the psychological symptoms in convicts by taking the convicts' resilience into account.

\section{AUTHORS' CONTRIBUTIONS}

Talitha Lintang Pertiwi: Data curation; Formal analysis; Writing-original draft. Dian Veronika Sakti Kaloeti: Data curation; Formal analysis; Writingoriginal draft

\section{ACKNOWLEDGMENTS}

This research was facilitated in the International Publication Research (RPI) 2019, funded by Universitas Diponegoro (329-89/UN7.P4.3/PP/2019). The authors would like to express their gratitude to Class 1 Semarang Correctional Institution for research program collaboration and all assisting inmates involved in this research.

\section{REFERENCES}

[1] F. Azzahra F. Pengaruh Resiliensi Terhadap Distress Psikologi terhadap Psikologis Mahasiswa. J Ilm Psikol Terap. 5(1), (2017)

[2] D. Gussak. The Arts in Psychotherapy The effects of art therapy on male and female inmates: Advancing the research base. vol. 36 .
2009, pp. 5-12.

[3] I. Herdiana. Profil Kecemasan Narapidana Wanita [Internet]. web.unair.ac.id. 2011. Available from: http://ikeherdianafpsi.web.unair.ac.id/artikel_detail-40803-Riset Sosial-Profil Kecemasan Narapidana Wanita.html

[4] A. Y. F. Pamungkas. Hubungan Dukungan Sosial dengan Tingkat Stres pada Warga Binaan Pemasyarakatan Perempuan di Lembaga Pemasyarakatan. J Holist Nurs Heal Sci. 2(2) (2019), 42-47

[5] A. DelaTorre-Luque, H. Gambara, E. Lopez, J. A. Cruzado. Psychological treatments to improve quality of life in cancer contexts: A metaanalysis. Int J Clin Heal Psychol. 16(2) (2016).

[6] F. Walsh. Family resilience: a developmental systems framework. Eur J Dev Psychol. 8, (2016).

[7] A. Batool, J. Malik, A. Nawaz. Relationship between self-regulation and quality of life: an intensive exploration in patients with diabetes. 2015.

[8] A. Bastaminia, M. R. Rezaei, Y. Tazesh. Resilience and quality of life among students of Yasouj State University. Int J Res Humanit Soc Stud. 3, (2016), 6-11.

[9] E. Gerino, L. Rollè, C. Sechi, P. Brustia. Loneliness, resilience, mental health, and quality of life in old age: A structural equation model. Front Psychol. 8, (20170, 1-12.

[10] C. Cheng, D. Dong, J. He, X. Zhong, \& S. Yao. Psychometric properties of the 10-item ConnorDavidson Resilience Scale (CD-RISC-10) in Chinese undergraduates and depressive patients. J Affect Disord. 261(211-220), (2020).

[11] L. Campbell-Sills, D. R. Forde, M. B. Stein. Demographic and childhood environmental predictors of resilience in a community sample. $\mathbf{J}$ Psychiatr Res. 43(12), (2009), 1007-1012.

[12] World Health Organization (WHO). WHOQOL: Measuring quality of life. 1997.

[13] A. R. Tirto, S. S. Turnip. The accuracy of Hopkins Symptom Checklist - 25 (HSCL-25) depression subscales ( Indonesian version ) on adolescents. 16(1), (2019), 1-12.

[14] T. L. Bris. The Hopkins symptoms checklist in 25 items: translations in Castilian, Galician, Catalan, French, Greek, Italian, Polish, Bulgarian and Croatian synthesis. 2017. 
[15] E. Mujahidah, R. A. Listiyandini. Pengaruh resiliensi dan empati terhadap gejala depresi pada remajaPengaruh resiliensi dan empati terhadap gejala depresi pada remaja. J Psikol. 14(1), (2018).

[16] J. Holt-Lunstad, T. B. Smith, J. B. Layton. Social relationships and mortality risk: A meta-analytic review. PLoS Med. 7(7), (2010).

[17] L. A. Greenfeld, T. L. Snell. Women Offenders. USA: Office of Justice Program, 1999. 